\title{
SERCE BARDZIEJ NIŻ ROZUM - ROMANTYCZNY POSTMODERNIZM JAKO WYZWANIE DUSZPASTERSKIE
}

DOI: http://dx.doi.org/10.12775/TiCz.2015.050

\section{TRADYCYJNA ANTROPOLOGIA I MORALNOŚĆ - CZYLI ROZUM BARDZIEJ NIŻ SERCE}

Koncepcja tradycyjna, obiektywistyczna - będąca punktem wyjścia niniejszych rozważań - prezentowała pewną spójną wizję antropologiczną i ściśle z niej wynikającą koncepcję moralną. „W niemiłym dla umysłu uproszczeniu" można tę tradycyjną koncepcję sprowadzić do zasadniczej myśli, mówiącej, że niektóre elementy naszej natury są chaotyczne i nieokiełznane - w związku z tym niższe, i powinny zostać zdyscyplinowane, zhierarchizowane i uporządkowane, tak by służyły temu, co w ludzkiej naturze wyższe, co nadaje człowiekowi godność - czyli pierwiastkowi duchowemu1. Innymi słowy życie prawdziwie ludzkie (godziwe) to życie rozumne. Moralność tradycyjna - ufundowana na trwałych, obiektywnych

* Mgr Mateusz Mazurek, teolog, absolwent Papieskiej Akademii Teologicznej w Krakowie, katecheta w Gimnazjum im. Kazimierza Wielkiego w Wieliczce, doktorant Uniwersytetu Pedagogicznego im. KEN w Krakowie.

${ }^{1}$ Por. R. Legutko, Raj przywrócony, Kraków 2005, s. 132. 
i odkrywanych przez rozum wartościach - postulowała podporządkowanie rozumowi właśnie impulsów, popędów, emocjil.

\section{PONOWOCZESNOŚĆ, CZYLI SERCE BARDZIEJ NIŻ ROZUM}

\subsection{POSTMODERNIZM}

W odniesieniu do powyższej koncepcji dominującą dziś wizję można w gigantycznym skrócie opisać jako odwrócenie ról. Opisanie wszystkich czynników, które do tego doprowadziły, znacznie przekracza rozmiary tego opracowania (a dodatkowo nie jest jego zasadniczym celem). Warto wskazać najważniejsze - a do tych zaliczyłbym „romantyczny postmodernizm" i konsumpcyjną kulturę niedojrzałości.

Jeśli chodzi o złożony nurt, jakim jest postmodernizm, to dla poniższych rozważań szczególnie istotne jest (w pewnym sensie sztandarowe) przekonanie epistemologiczne, które można streścić ${ }^{2}$ w zdaniu „zewnętrzna wobec człowieka, obiektywna prawda nie istnieje”, a w związku z tym uprawnione jest mówienie tylko o wielości subiektywnych narracji. Uzasadnieniem takiego stwierdzenia ma być (skądinąd prawdziwe) spostrzeżenie, że ta sama rzeczywistość odbierana jest w różny sposób przez poszczególne osoby; inaczej wygląda z różnych perspektyw ${ }^{3}$. W powyższym rozumowaniu rzuca się w oczy przeskok myślowy od prawdziwej przesłanki do bardzo wątpliwego wniosku4 . Nie zmienia to jednak faktu, że postmodernizm (nawet jeśli jego popularność, przynajmniej w niektórych dziedzinach, spada $)^{5}$ wywarł ogromny wpływ na mentalność

2 Mamy tu oczywiście do czynienia z „niemiłym dla umysłu uproszczeniem”, koniecznym jednak ze względu na objętość i charakter opracowania.

${ }^{3}$ Por. np. E. Babbie, Podstawy badań społecznych, W. Bentkiewicz i in. (tłum.), Warszawa 2013, s. 26-27.

${ }^{4}$ Czym innym uznanie, że absolutna prawda jest nam niedostępna (poznajemy tylko jej aspekty), a czym innym stwierdzenie, że nie istnieje. Por. W. Starnawski, Źródła $i$ pedagogiczne konsekwencje redukcjonizmu antropologicznego, „Paedagogia Christiana” 2/29 (2012), s. 17-18.

5 Por. P. Sztompka, Socjologia. Analiza społeczeństwa, Kraków 2012, s. 632. 
współczesną ${ }^{6}$. Wpływ ten przejawia się także poprzez filozoficzne uzasadnienie mającego własne źródła (o których poniżej), a powszechnego dziś irracjonalizmu. Skoro nie istnieje prawda, rozum nie ma punktu oparcia i nieodwołalnie traci znaczenie. Skoro liczą się tylko nasze narracje, osobiste perspektywy - to czynniki bardzo subiektywne (emocje) stają się co najmniej tak samo uzasadnione i prawomocne jako wyznacznik decyzji, jak to, co stałe, obiektywne i rozumowo odkrywane (np. prawo naturalne).

\subsection{KONSUMPCYJNA KULTURA NIEDOJRZAŁOŚCl}

Postmodernizm, unieważniający sens konfrontowania teorii z rzeczywistością, podważający znaczenie prawdy czy słuszności jako kryterium wartości danej koncepcji, doprowadził jednocześnie do upowszechnienia innych kryteriów - oryginalności, osobliwości, niewspółmierności ${ }^{7}$. $\mathrm{W}$ tym momencie spotyka się i dobrze koresponduje ${ }^{8} \mathrm{z}$ procesami społecznymi konstytuującymi kulturę konsumpcyjną. O ile w tradycyjnym sposobie myślenia (i wypływającej z niego praktyce) wartościowe było

${ }^{6}$ Nie tylko na (źródłową dla siebie) teorię literatury, ale także np. na psychologię i terapię - gdzie subiektywistyczne ujęcie wskazuje tylko na czynniki emocjonalne, niezależne od człowieka (poznając osobowościowe przyczyny problemów możliwe do usunięcia przez panowanie nad sobą) i zewnętrzne (społeczne) - terapia nie jest więc usunięciem obiektywnej trudności, ale polepszaniem samopoczucia, ewentualnie służy przystosowaniu jednostki do układu społecznego. Por. W. Starnawski, Źródła i pedagogiczne konsekwencje redukcjonizmu antropologicznego, s. 14. Najciekawszy wydaje się jednak wpływ tej intelektualnej mody na duszpasterstwo - które skupia się na czynnikach emocjonalnych, pomijając lub marginalizując wymiar apelowania do wolności (związanej nieodłącznie z rozumnością) człowieka. Por. R. Woźniak, Chrześcijaństwo i lęk z punktu widzenia wyzwań nowej ewangelizacji. Referat wygłoszony w ramach Dni Katechetycznych w Krakowie 29 sierpnia 2013 r.

7 Por. W. Starnawski, dz. cyt., s. 19.

${ }^{8}$ Czasem bywa też przedstawiany jako źródło tych zmian społecznych. Por. np. D. Bell, Kulturowe sprzeczności kapitalizmu, tłum. S. Amsterdamski, Warszawa 1998, s. 88-89. Dla poniższych rozważań nie wydaje się konieczne jednoznaczne rozstrzyganie o kierunku związków przyczynowo-skutkowych, wystarczające jest odnotowanie współzależności. 
to, co trwałe, niezmienne (najlepiej wieczne), to w społeczeństwie ponowoczesnym zmiana, nowość postrzegana jest jako wartość sama w sobie .

Żelazne prawo świata mody brzmiące: everything new is beautiful ${ }^{10}$ staje się coraz istotniejszym składnikiem mentalności współczesnej.

9 Por. np. D. Bell, dz. cyt., s. 68-69; T. Leszniewski, Moda i tożsamość. Dylematy współczesnego człowieka w świecie konsumpcji, [w:] T. Szlendak, K. Pietrowicz, Rozkoszna zaraza. O rządach mody i kulturze konsumpcji, Wrocław 2007, s. 60-61. Wynikać to może z wielu czynników - można wśród nich wskazać cztery zasadnicze:

- Globalizacja - związane ze zmianami technologicznymi i kulturalnymi przyspieszenie przepływów zarówno towarów i ludzi, jak i idei, wzorców zachowań itp. Por. np. P. Sztompka, dz. cyt., s. 648-67; A. Giddens, Socjologia, tłum. A. Sulżycka, Warszawa 2006, s. 75-96; M. Albrow, Globalizacja: teoretyczne aspekty zmian, tłum. K. Gilarek, [w:] P. Sztompka, M. Kucia (red.), Socjologia. Lektury, Kraków 2005, s. 688-695; J. Urry, „Społeczeństwa” i wymiar globalny, tłum. K. Gilarek, [w:] P. Sztompka, M. Kucia (red.), dz. cyt., s. 697-698; M. Kaldor, Globalizacja, państwo i wojna, tłum. K. Gilarek, [w:] P. Sztompka, M. Kucia (red.), dz. cyt., s. 715-716.

- W pewnym stopniu powiązana z powyższym zmienność zewnętrznego otoczenia (świata rzeczy). Por. J. Baudrillard, Społeczeństwo konsumpcyjne jego mity i struktury, tłum. S. Królak, Warszawa 2006, s. 8.

- Coraz większy wpływ na nasze życie i postawy mediów wizualnych z ich migotliwością, mającą zapewnić atrakcyjność ciągle rosnącą szybkością ujęć kamery, zmian nastrojów. N.R. Bellah i in., Skłonność serca. Indywidualizm i zaangażowanie po amerykańsku, tłum. D. Stasiak i in., Warszawa 2007, s. 437-438.

- Wypieranie przez modę obyczaju jako zasadniczego regulatora zachowań. W świecie mody - aby mogła ona pełnić swoją funkcję, czyli odróżnianie klas, musi następować zmiana. Im szybciej klasy niższe naśladują np. dzięki podróbkom styl klas wyższych, tym szybciej te muszą zmieniać obowiązujące kanony. Por. np. G. Simmel, Filozofia mody, tłum. S. Magla, [w:] P. Sztompka, M. Kucia (red.), dz. cyt., s. 274-276; T. Szlendak, K. Pietrowicz, Moda, wolność i kultura konsumpcji, [w:] T. Szlendak, K. Pietrowicz, dz. cyt., s. 10-13; T. Kozłowski, Wykichana kultura. Wirusy, pandemie, mody, [w:] T. Szlendak, K. Pietrowicz, dz. cyt., s. 31; M. Kempny, dz. cyt., s. 8; T. Leszniewski, dz. cyt., s. 50; G. Ritzer, Makdonaldyzacja społeczeństwa. Wydanie na nowy wiek, tłum. L. Stawowy, Warszawa 2003, s. 243.

${ }^{10}$ Por. D. Antonowicz, Unisex i ultrasi, [w:] T. Szlendak, K. Pietrowicz, dz. cyt., s. 72 . 


\section{SKUTKI SPOŁECZNE I DUSZPASTERSKIE}

\subsection{ZANIK POJĘClA WIERNOŚCl}

Jeśli wszystko, co nowe, jest dobre i piękne (tylko dlatego, że nowe), wówczas pojęcie wierności traci sens albo nawet staje się antywartością. Wierności w szerokim rozumieniu - wobec Boga, współmałżonka, przyjaciela, wyznawanych wartości czy podjętych zobowiązań. Wierność jest podstawą trwałości stosunków społecznych ${ }^{11}$. Wyeliminowanie jej $\mathrm{z}$ horyzontu aksjologicznego musi doprowadzić do osłabienia więzi międzyludzkich.

W rzeczywistości w kulturze konsumpcyjnej możemy zaobserwować gloryfikowanie tylko jednego, bardzo specyficznego rodzaju wierności wobec samego siebie, a konkretniej wobec swoich zachcianek i porywów serca. Określa się taką postawę mianem autentyczności. Mit autentyczności sprawia, że każdy sam dla siebie stanowi normę ${ }^{12}$, w dziedzinie postaw i ocen moralnych, podobnie jak w aksjologii musi doprowadzić to do subiektywizmu i relatywizmu.

\subsection{RELATYWIZM}

Richard Rorty twierdzący, że np. opisy komunizmu: skrajnie afirmatywny - Sartre’a i niezwykle krytyczny - Orwella, są tak samo wartościowe oraz że nie istnieje neutralne stanowisko, z którego można argumentować, że tortury są gorsze od życzliwości ${ }^{13}$, może posłużyć jako wymowny przykład myślenia, o którym tutaj mowa. Jego kluczowym założeniem jest niemożliwość odróżniania prawdy od fałszu, wskazania jakiegoś zewnętrznego trybunału, który mógłby służyć do rozstrzygania naszych debat ${ }^{14}$. W sposobie myślenia określanym tutaj jako tradycyjny takim zewnętrznym wobec człowieka kryterium były obiektywne war-

${ }^{11}$ Por. T. Leszniewski, dz. cyt., s. 56-57.

12 Por. R. Legutko, Złośliwe demony, Kraków 1999, s. 171.

13 Por. W. Starnawski, dz. cyt., s. 24.

14 Por. R. Legutko, O czasach chytrych i prawdach pozornych, Kraków 1999, s. $121-122$. 
tości: Prawda w dziedzinie poszukiwań intelektualnych, Dobro w sferze moralnej. W ujęciu postmodernistycznym nasze decyzje (podobnie jak dyskurs) mogą się opierać tylko na wartościach estetycznych (rozumianych subiektywnie), emocjonalnych - coś mi się podoba, zastępuje stwierdzenie, że coś jest prawdziwe lub dobre (słuszne). Świat rządzony przez (z natury niestałe) emocje, w którym są one ostatecznym wyznacznikiem, skazany jest na nietrwałość wszystkiego - z relacjami międzyludzkimi włącznie. Wspólnota życia budowana wyłącznie na „porywach serca” może trwać tylko tak długo, jak owe porywy. Trudno w takim ujęciu mówić o związkach na całe życie. Irracjonalizm i subiektywizm naszych czasów prowadzące do prostego utożsamiania tego, co przyjemne, z tym, co dobre, skutkują także zmianami języka - który jak wiadomo kształtuje ludzkie myślenie, a co za tym idzie działanie. Niezwykle istotną zmianą w tej dziedzinie jest utożsamienie tego, co niewątpliwie dobre - miłości, z czymś, co niewątpliwie przyjemne - zakochaniem ${ }^{15}$. Uczucie to, piękne na pewnym etapie, okazuje się "fatalnym sposobem na resztę życia”" Trudno się dziwić lawinowemu wzrostowi liczby rozwodów, biorąc pod uwagę choćby tylko opisane powyżej czynniki (na zjawisko to wpływają oczywiście także inne procesy społeczne).

\subsection{SKUTKI WYCHOWAWCZE}

Oczywiście powyższe zjawiska generują poważne trudności na płaszczyźnie wychowania, także (a może szczególnie) wychowania religijnego. Najistotniejszy wydaje się problem wzorców przekazywanych dzieciom przez niewiernych rodziców. Postawa "pierwszych wychowawców” może wytwarzać w dziecku przekonanie, że wierność w ogóle nie jest możliwa. Dodatkowo należy brać pod uwagę, że rodzice są dla dziecka pierwszymi figurami Boga, ich miłość jest najbardziej naturalnym i podstawowym obrazem miłości Boga. Niezwykle głębokim, biorąc pod uwagę

${ }^{15}$ Nie mówiąc już o skrajniejszym przykładzie takiej redukcji terminologicznej - nazywaniu miłością samego współżycia seksualnego.

${ }^{16}$ J. Zimny, Zasady pedagogiki wobec „Dżumy XXI wieku”, „Pedagogika Katolicka”. Czasopismo Katedry Pedagogiki Katolickiej Wydziału Zamiejscowego Nauk o Społeczeństwie KUL w Stalowej Woli, 10 (2012) 1, styczeń-czerwiec, s. 25. 
współpracę rodziców w dziele stwarzania nowego życia. Jeżeli ten fundamentalny obraz się rozpada, nabranie przez dziecko przekonania, że Bóg nie istnieje, delikatnie rzecz ujmując, nie wydaje się sprawą niemożliwą.

Drugą trudnością jest relatywizm moralny i aksjologiczny. Szalenie trudno jest mówić o realizowaniu jakiegokolwiek dobra, obiektywnych wartości ludziom wzrastającym w atmosferze kulturowej przesiąkniętej przekonaniem, że żadne obiektywne wartości nie istnieją. Jak więc ich realizowanie miałoby być drogą do pełni człowieczeństwa? Równie trudno jest mówić o jakiejś wierności (wobec Boga, ludzi, wartości) - skoro jedynym ośrodkiem decyzyjnym mają być zmienne z natury emocje. Wiara w Boga oparta na emocjach zamiast na rozumie i decyzjach woli jest chwiejna, niestała (jak same emocje) - „nieodporna na przeciwności i trudności, które mogłyby ją łamać” ${ }^{17}$. Przeżycie emocjonalne może być bardzo wartościowym punktem wyjścia, wstępem czy pierwszym krokiem do wiary, jednak samo w sobie - jeśli nie zostanie umocnione racjonalnymi decyzjami woli, nie może stanowić solidnego fundamentu, na którym wiara mogłaby trwać, dojrzewać i wzrastać. Innymi słowy, ten emocjonalny pierwszy krok, żeby rzeczywiście przyniósł trwałe duchowe owoce, musi pociągnąc za sobą następne: angażujące rozum i wolę. Wykonanie kolejnych kroków na drodze wiary jest szalenie utrudnione, jeśli uznaje się emocje za jedyny bądź najważniejszy ośrodek decyzyjny. $\mathrm{Z}$ drugiej strony dojrzewanie wiary (jak powiedziano, koniecznie wymagające zaangażowania rozumu i woli) może być ogromnym wsparciem dla ludzkiego procesu dojrzewania emocjonalnego, które można określić też jako (samo)wychowanie emocjonalne.

Trzeba także zauważyć, że ten proces wychowywania emocji - najprościej rzecz ujmując, polegający na pracy nad tym, żeby je zrozumieć, opanować i nauczyć się kierować tą sferą ${ }^{18}$ - we współczesnej kulturze staje się czymś problematycznym. Nie tylko dlatego, że atmosfera kulturowa nie ułatwia osiągnięcia ideału w postaci dojrzałości emocjonalnej, ale także dlatego, że utrudnia w ogóle uznanie tego ideału za pożądany cel

17 Por. W. Cichosz, Pedagogia wiary we wspótczesnej szkole katolickiej, Warszawa 2010, s. 151. Cyt. za: Z. Marek, Religia pomoc czy zagrożenie dla edukacji?, Kraków 2014, s. 39 .

18 J. Zimny, dz. cyt., s. 22-26. 
dążeń. Wręcz przeciwnie - w kulturze niedojrzałości wzorem do naśladowania stają się właśnie ludzie niedojrzali (dzieci i młodzież), spontanicznie kierujący się emocjami, zachciankami itp. ${ }^{19}$ Bp Grzegorz Ryś, komentując wers z Hymnu o miłości: „Gdy byłem dzieckiem, mówiłem jak dziecko, czułem jak dziecko, myślałem jak dziecko. Kiedy zaś stałem się mężem, wyzbyłem się tego, co dziecięce" (1Kor 13,11), stwierdza, że dziecko ma prawo być zmienne, nikt nie wymaga od niego wierności. Natomiast człowiek dorosły (dojrzały) powinien w swojej miłości trwać, nie uciekać $\mathrm{w}$ coś innego, nie przerzucać się z miejsca na miejsce, $\mathrm{z}$ uczucia w uczucie czy z postanowienia w postanowienie. Miłość takiego człowieka powinna być zdolna do decyzji wiążących na całe życie (innymi słowy powinien dać się przybić do krzyża) ${ }^{20}$. Taka postawa pozwala osobom, które zintegrowały emocje $\mathrm{z}$ dojrzałą postawą wobec siebie i odpowiedzialną miłością wobec innych, budować trwałą rodzinę - dobry grunt dla dojrzewania kolejnych pokoleńn ${ }^{21}$.

\section{PODSUMOWANIE: WAŻNE PYTANIE DUSZPASTERSKIE}

Najprostszy wniosek wypływający z powyższych rozważań mógłby brzmieć: jest trudno, a czasy są złe. Świadomość tego, jak świat wartości wyznawanych w zachodniej kulturze oddala się od chrześcijaństwa, może prowadzić do narzekania na współczesny świat, ale powinna raczej skłaniać chrześcijan do umocnienia przekonania, że ten świat (może jeszcze bardziej niż jakiś czas temu) potrzebuje naszego przepowiadania i świadectwa. To pierwsze może być trudniejsze, jako że ludzie, do

19 Por. R. Legutko, Złośliwe demony, s. 37, 80, 149; D. Bell, dz. cyt., s. 103-105; M. Bogunia-Borowska, Dziecko w kulturze konsumpcyjnej - infantylizacja kultury jako konsekwencja narodzin podmiotu rynkowego, [w:] A. Jawłowska, M. Kempny, Konsumpcja istotny wymiar globalizacji kulturowej, Warszawa 2005, s. 159-177; M. Biedroń, Kidults, czyli moda na niedorastanie, [w:] W. Muszyński (red.), „Nowy wspaniały świat? Moda, konsumpcja i rozrywka jako nowe style życia, Toruń 2009, s. 181-192.

20 Por. G. Ryś, Rekolekcje, Modlitwa, Jałmużna, Post, Kraków 2013, s. 103.

${ }^{21}$ J. Zimny, dz. cyt., s. 26. W oczywisty sposób mechanizm ten działa też w drugą stronę - założona przez ludzi niedojrzałych, nietrwała rodzina utrudnia dojrzewanie emocjonalne dzieciom, przez co zmniejsza szansę, że im uda się w przyszłości zbudować trwałą rodzinę. 
których idziemy, wyznają wartości biegunowo odmienne od tych, które mamy im do zaproponowania, ale $\mathrm{z}$ drugiej strony (paradoksalnie $\mathrm{z}$ tego samego powodu) świadectwo chrześcijan - życie wartościami zupełnie zapomnianymi przez współczesność - może okazać się szczególnie wyraziste i fascynujące. Być może wracamy do czasów, kiedy człowiek żyjący zwyczajnie po chrześcijańsku żyje zupełnie inaczej niż reszta społeczeństwa $^{22}$. Chyba że ulegniemy pokusie dostosowania się - jak światło, które postanawia przygasnąć, żeby za bardzo nie odróżniać się od ciemności.

Dotknęliśmy tutaj niemal odwiecznego problemu związanego $\mathrm{z}$ granicami inkulturacji. $\mathrm{Z}$ jednej strony musimy brać pod uwagę mentalnościowe i społeczne uwarunkowania tych, którym chcemy głosić Ewangelię, z drugiej strony musimy zawsze być wyczuleni na pokusę dopasowywania orędzia ewangelii do mentalności pogańskiego świata, bo jeżeli jej ulegniemy, wówczas nie będzie czego głosić ${ }^{23}$.

W trakcie studiów usłyszałem podczas jednej dyskusji na temat inkulturacji pytanie: czy trzeba z kogoś zrobić tomistę, żeby mu głosić ewangelię? Można zapytać inaczej: Czy trzeba najpierw kogoś wychować, ukształtować, uformować na człowieka rozumu (kierującego się bardziej rozumem niż emocjami), żeby uczyć go wiary i życia ewangelicznymi wartościami? W moim rozumieniu procesy te powinny przebiegać (do pewnego stopnia) równolegle. Do pewnego stopnia, bo wydaje się oczywiste, że ewangelizacja jest zawsze czymś podstawowym (zarówno w porządku chronologicznym, jak i w porządku wagi, znaczenia). Głosić Chrystusa zmartwychwstałego powinniśmy więc zawsze człowiekowi takiemu, jaki jest. Żeby jednak owoce były trwałe, potrzebna jest katechizacja, dalsza formacja - tu jest właściwe miejsce i czas na formowanie także głębszych, osobowościowych cech i postaw, na stopniowe przekształcanie

${ }^{22}$ Dla przykładu - mąż, który po prostu jest, nie zostawia swojej żony, staje się powoli coraz większym ewenementem (choć kilka dekad temu niczym by się nie wyróżniał). Oczywiście dla społeczeństwa jest to sytuacja tragiczna, dla dzieci zniszczonych rozwodem rodziców jeszcze bardziej. Wszystkie społeczne, psychologiczne i emocjonalne problemy związane z plagą rozwodów uwypuklają, jak bardzo współczesny świat potrzebuje chrześcijańskiego świadectwa.

${ }^{23} \mathrm{~W}$ pewnym sensie dylemat ten jest analogiczny do tego, przed jakim stanął Winston Churchill, który na propozycję zmniejszenia wydatków na kulturę ze względu na koszty działań wojennych miał odpowiedzieć „A o co wtedy będziemy toczyć tę wojnę?!”. 
mentalności w kierunku coraz lepiej korespondujących z ewangeliczną aksjologią.

Dobrze jest więc - w moim rozumieniu - znać uwarunkowania wpływające na współczesnego człowieka, jego mentalność i moralność. Nie wolno jednak zapominać, że łaska Boża jest zdolna przemieniać człowieka bardzo głęboko, dać mu naprawdę nową naturę $(\mathrm{Rz} 8)$, więc także nową mentalność, i to niezależnie od tego, jak bardzo pogańska była stara. Śmierć starego człowieka uzależniona jest od odpowiedzi człowieka na darmową łaskę Boga, nie zaś od tego, na ile ten „stary” był podobny do „nowego”, którym ma się stać ${ }^{24}$. Związana jest z tym ogólniejsza refleksja na temat społecznego zaangażowania chrześcijan - owszem, powinniśmy dążyć do tego, żeby nasze społeczeństwo było coraz mniej oddalone od chrześcijańskich wartości. Będzie wtedy bardziej ludzkie i będzie człowiekowi ułatwiało prowadzenie chrześcijańskiego życia; ale musimy zawsze pamiętać, że pierwszorzędnym zadaniem Kościoła nie jest tworzenie społeczeństwa zbliżonego do ewangelicznego ideału, ale głoszenie ewangelii - w społeczeństwie takim, jakie ono jest.

Zarysowane w niniejszych rozważaniach problemy społeczne wymagają przemyślenia i roztropnego ułożenia relacji między ewangelizacją a katechezą (formacją). W przekonaniu autora tych słów dwie kwestie jawią się jako oczywiste: to, że te dwa rodzaje działalności duszpasterskiej powinny przenikać się wzajemnie szczególnie w katechezie szkolnej, ze względu na bardzo zróżnicowany poziom wiary jej uczestników) oraz to, że ewangelizacja jest zawsze działalnością pierwotną, fundamentalną. Trzymając się ewangelicznej metafory Słowa Bożego jako ziarna, trzeba podkreślić, że nie ma żadnego sensu pielęgnowanie, uprawianie i próby zbierania czegoś, co nie zostało zasiane. Katechizacja, która nie została poprzedzona ewangelizacją, innymi słowy uczenie ludzi niewierzących, jak żyć po chrześcijańsku, nieodparcie wywołuje we mnie skojarzenie $\mathrm{z}$ rolnikiem z dowcipu, który wjeżdżając kombajnem na pole, puka się w czoło, mówiąc „zapomniałem zasiać”. Jest jednak także druga strona

${ }^{24}$ Powyższe uwagi nie mają absolutnie na celu usprawiedliwiania zaniedbywania współpracy z łaską Bożą ( $w$ tym przypadku przez chrześcijańskie wychowanie i samowychowanie), ale podkreślenie, że załamywanie rąk, „bo jest trudno i czasy są złe”, jest postawą sprzeczną z wiarą. 
tego zagadnienia, którą warto widzieć i brać pod uwagę - im trudniejsze są warunki zewnętrzne, tym więcej wysiłku potrzeba, żeby zasiane ziarno wydało plon. Im bardziej antychrześcijańska jest kultura, tym ważniejsze staje się, żeby nie pozostawić bez solidnej formacji tych, którzy uwierzyli.

Streszczenie. Artykuł rozpoczyna się od opisu dwóch centrów decyzyjnych w człowieku: emocji i intelektu (określonych tu jako serce i rozum). Następnie opisuje proces zmian w kulturze i filozofii skutkujący zmianą postrzegania czynników emocjonalnych i nadawaniem im coraz większego znaczenia. Podjęta zostaje również analiza najważniejszych - społecznych, kulturowych i duszpasterskich - skutków tego procesu ze szczególnym uwzględnieniem niestałości decyzji i zobowiązań powodującej kryzys instytucji rodziny.

Słowa kluczowe: emocje; rozum; postmodernizm; niestałość decyzji; kryzys instytucji rodziny.

Abstract. The Heart Rather Than the Mind - Romantic Postmodernism as a Pastoral Challenge. The article begins with a description of two decision-making centers in people - emotions and intellect (referred to herein as heart and mind). The article describes the process of changes in the culture and the philosophy. The changes resulting in changing the perception of emotional factors and giving them increasingly important. The article also analyses the most important social cultural and a pastoral implications of this process. Special attention is paid to instability of the decision and obligations causing crisis of the institution of the family.

Key words: emotions; intellect; postmodernism; instability of decision; crisis of the institution of the family. 
